\title{
SYNTHESIS, IDENTIFICATION AND BIOLOGICAL ACTIVITY OF NEW HETEROCYCLIC COMPOUNDS FROM REACTION OF NEW SCHIFF-BASES WITH PHATHALIC ANHYDRIDE
}

\author{
Alya A. Dawood ${ }^{\mathrm{a}, *}$, Shireen R. Mohammed ${ }^{\mathrm{a}}$, Mohammed Mahmoud ${ }^{\mathrm{a}}$ \\ ${ }^{a}$ Dept. of Chemistry, Faculty of Science, University of Zakho, Kurdistan Region, Iraq- (alya.dawood; shireen.mohammed; \\ mohammed.babaker)@uoz.edu.krd
}

Received:Sep., 2019 / Accepted:Dec., 2019 / Published: Mar.,2020

https://doi.org/10.25271/sjuoz.2020.8.1.641

\begin{abstract}
:
Series of new Schiff bases and their derivatives (Oxazepine) have been synthesized during two steps. The first step synthesis of imines derivatives (1-10) by the condensation reaction of 1,7-diaminohepatane and 1,8-diaminooctane with different substituted aromatic aldehydes by using glacial acetic acid as catalyst. The second step includes reaction of the prepared Schiff bases derivatives with phathalic anhydride in dry benzene to obtain seven -membered heterocyclic ring derivatives (1 1-15). The biological activities of some prepared compounds were also studied against different kinds of bacteria.The new derivatives were confirmed by suing a range of experimental techniquesincluding ${ }^{1} \mathrm{HNMR},{ }^{13} \mathrm{C} \mathrm{NMR}$, IR and Mass spectra.
\end{abstract}

KEYWORDS: Oxazepine, Schiff bases, 1, 7-diaminoheptane, 1, 8-diaminooctane, Antibacterial activity,Phathalic anhydride.

\section{INTRODUCTION}

The chemistry of the imine group isconsidered to be a significant part in the progress of chemistry science (Yang et al, 2002; Al Jeboori et al, 2008). Schiff bases which characterizing by a double bond $(-\mathrm{CH}=\mathrm{N}-)$ are generally prepared by condensation method of aromatic aldehyds or ketoneswith primary amines (Celik et al, 2009; Saeed, 2005). Schiff -bases showed different biological activities such as antibacterial, antifungal and antitubercular (Wadher et al, 2009; Mohammed et al, 2019). Many heterocyclic compounds were prepared from the $\mathrm{S}$ chiff bases, for example oxazepines derivative which indicate a seven membered ring involving oxygen and nitrogen atoms in addition to five carbon atoms (Khattar et al, 2004; Aljamali et al, 2014). Over the years, the synthesis of oxazepine has been studie $d$ and attested. The oxazepine is prepared from addition of Schiff bases with maleic, phthalic and succinic anhydrides (Hanoon, 2011; Abood, 2010; Sadiq, 2017; Taha, 2017; Abdul-Wahid et al, 2016; Abdullah et al, 2016; Hamak and Eissa, 2013; Abood, 2013; Abdulqahar and Jaber, 2016; Aljamali, 2013) and also by green chemistry method (Verma et al, 2015; Hameed, 2012). A vast variety of biological activities were found to show of Oxazepine derivatives such as antibacterial (Agirbas et al, 2011), antifungal (Serrano-Wu et al, 2002), hypnotic muscle relaxant (Abedel -Hahez and Abdel Wahab, 2008), antagonistic (Hallinan et al, 1996), inflammatory (Kubota et al, 2011) and antiepileptic (Bajajt et al, 2003).

Because of the biological importance of these compounds, the aim of this work is to synthesize some new Schiff bases and oxazepine derivatives as shown in Scheme 1 and investigate their biological activities against different kinds of bacteria

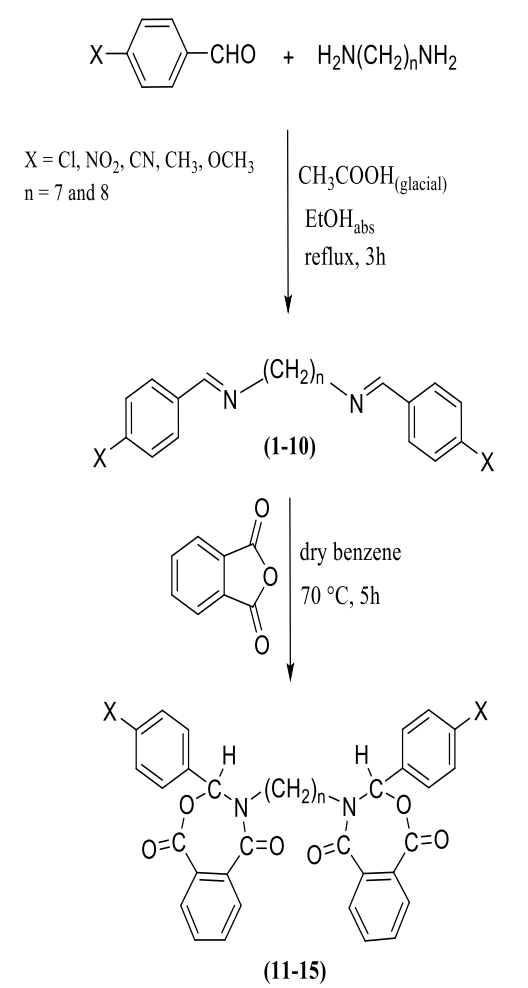

Scheme1: Synthetic rout of preparation of schiff bases and oxazepine derivatives.

* Corresponding author
This is an open access under a CC BY -NC-SA 4.0 license (https://creativecommons.org/licenses/by -nc-sa/4.0/) 


\section{EXPERIMENTAL DATA}

\subsection{General: Equipments, Chemical Materials and Applied Techniques}

All reactions were carried out with dry in solvents under anhydrous conditions. Commercial reagents were used without purification. Ethanol was used as absolute solvent. ${ }^{1} \mathrm{H}-\mathrm{NMR}$ and ${ }^{13} \mathrm{C}-\mathrm{NMR}$ were recorded on Bruker DPX-300FT $\left({ }^{1} \mathrm{H}: 300 \mathrm{MHz}\right.$, ${ }^{13} \mathrm{C}$ : $\left.75.5 \mathrm{MHz}\right)$. All NMR spectra present in this work were measured in $\mathrm{CDCl}_{3}$ solution. All chemical shifts are given in ppm. The chemical shifts $(\delta)$ is expressed in ppm. The following abbreviations were used to explain the multiplicities: $\mathrm{s}=$ singlet, $\mathrm{d}=$ doublet, $\mathrm{t}=$ triplet, $\mathrm{q}=$ quartet, $\mathrm{m}=$ multiplet, $\mathrm{b}=$ broad. High resolution mass spectra were recorded on a Micro-mass ZABSpec TOF, on a Q-Tof Applied Biosystems and on Waters Q-Tof 2 apparatus. IR spectra were recorded on a Perkin-Elmer 1710 spectrophotometer or on a Perkin-Elmer Aragon 1000 FT-IR spectrophotometer. Thin Layer Chromatography (TLC) Merck Kiese gel 60 F254 on aluminum foil from Macherey-Nagel. Melting points were determined by electrothermal apparatus and are uncorrected.

2.2 General Procedure for Preparation N, N'- (alkane1,7-diyl) and (alkane-1,8-diyl) bis(1-(4-substituted phenyl) methanimine (1-10)

A mixture of aromatic aldehydes (1.6 mmol, 2 eq.), 1,7diaminoheptane, 1,8 -diaminooctane $(0.8 \mathrm{mmol}, 1$ eq. $)$ and 5 drops of glacial acetic acid in $50 \mathrm{ml}$ of dry ethanol were heated by reflux for (2-3) hours under dry conditions. Then ethanol was evaporated by vacuum. Finally, the solid compound was purified twice using absolute ethanol to obtain a pure product (1-10) (Ghosh et al, 2006; Aljamali, 2013) as shown in Table 1.

Table 1. The physical properties and Mass spectroscopy of N, N'-(Naphthaline-1, 5-diyl) bis Ketone Derivatives (1-10).

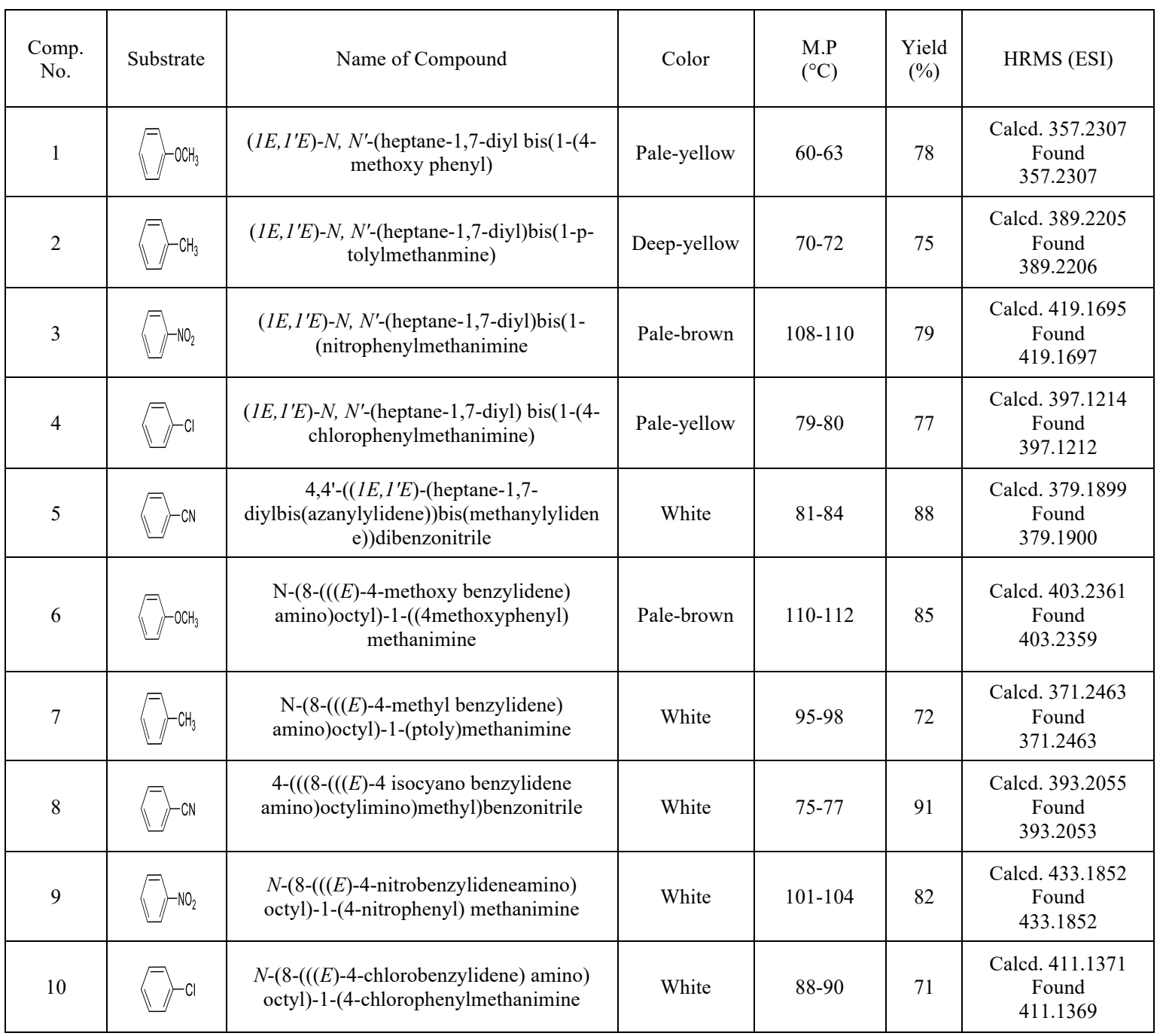

\subsection{Preparation of oxazepine compounds (11-15)}

Schiff base derivatives (1-10) (1.2 mmol, 1eq.) and phthalic anhydride $18(2.5 \mathrm{mmol}$, 1eq.) were dissolved in $(20 \mathrm{~mL})$ dry benzene. The mixture was heated for 5 hours in water bath at (70 $\left.{ }^{\circ} \mathrm{C}\right)$. The mixture was then allowed to cool down at room temperature; a formed precipitate was filtered and recrystallized from ethanol to obtain a pure product. (Hamak and Eissa, 2013; Al-juburi, 2012) as shown in Table 2. 
Table 2. The physical properties of oxazepane derivatives (11-15).

\begin{tabular}{|c|c|c|c|c|}
\hline Comp. No. & Name of Compound & Color & $\begin{array}{l}\text { M.P } \\
\left({ }^{\circ} \mathrm{C}\right)\end{array}$ & $\begin{array}{c}\text { Yield } \\
(\%)\end{array}$ \\
\hline 11 & $\begin{array}{c}\text { 4,4'-(octane-1,8-diyl)bis(3-(4-nitrophenyl } \\
\text { )-3,4-dihydrobenzo[e][1,3] oxazepine-1,5 } \\
\text {-dione) }\end{array}$ & White & $143-145$ & 80 \\
\hline 12 & $\begin{array}{c}\text { 4,4'-(heptane-1,7-diylbis(1,5-dioxo-1,3,4,5 } \\
\text {-tetrahydrobenzo[e][1,3]oxazepine-4,3-diyl } \\
\text { )) dibenzonitrile }\end{array}$ & White & $104-107$ & 78 \\
\hline 13 & $\begin{array}{l}\text { 4,4'-(heptane-1,7-diyl)bis(3-(p-tolyl)-3,4- } \\
\text { dihydrobenzo[e][1,3]oxazepine-1,5-dione) }\end{array}$ & White & $169-173$ & 70 \\
\hline 14 & $\begin{array}{c}\text { 4,4'-(heptane-1,7-diyl)bis(3-(4-methoxy } \\
\text { phenyl)-3,4-dihydrobenzo[e][1,3] } \\
\text { oxazepane -1,5-dione }\end{array}$ & White & $171-174$ & 75 \\
\hline 15 & $\begin{array}{c}\text { 4,4'-(octane-1,8-diylbis }(1,5 \text {-dioxo-1,3,4, } \\
\text { 5-tetrahydrobenzo[e][1,3] oxazepine-4,3-diyl)) } \\
\text { dibenzonitrile }\end{array}$ & White & $120-124$ & 85 \\
\hline
\end{tabular}

\subsection{Preliminary Biological Study}

All newly synthesized compounds were tested against two types of bacterial groups including Gram-negative, E. coil and Grampositive Staphylococcus aureus as shown in Table 3. Of each bacterial kind a loopful was maintained in a nutrient broth and incubated at $37^{\circ} \mathrm{C}$ for 14-16 hours. Finally, bacterial spread on nutrient agar using a sterilized swab. For comparison, Tetracycline, Lincomycine and Nalidixic acid were used as controls. The dishes were incubated for $18-24$ hours at $37^{\circ} \mathrm{C}$. Prescott method was used to clarify the sensitivity of the studied compounds (Prescott et al, 1996). The results interpreted according to the report of W.H.O. The resistance R explains the diameter of inhibition zone $<11 \mathrm{~mm}$, while the sensitive $\mathrm{S}$ was over $16 \mathrm{~mm}$, but moderately sensitive MS was involved when the inhibition zone is $12-16 \mathrm{~mm}$.

\section{RESULTS AND DISCUSSION}

The first part in this work was the synthesis of ten Schiff bases (1-10) from the reaction of (4-substituted benzaldehydes) with primary aliphatic amines in the presence of glacial acetic acid as catalyst in absolute ethanol. The IR spectra of Schiff base compounds (1-10) appeared the medium bands at 1640$1651 \mathrm{~cm}^{-1}$ assigned to the stretching vibration of imine group $(\mathrm{C}=\mathrm{N})$, and the disappearance of stretching band of $(\mathrm{C}=\mathrm{O})$ group. The absorption bands showed in the range of (1560-1606) $\mathrm{cm}^{-1},(3020-3089) \mathrm{cm}^{-1},(2920-2935) \mathrm{cm}^{-}$ ${ }^{1}$, related to the stretching vibrations of $(\mathrm{C}=\mathrm{C})$ aromatic, $(\mathrm{C}-\mathrm{H})$ aromatic, $(\mathrm{C}-\mathrm{H})$ aliphatic respectively as shown in Table 3.

The ${ }^{1} \mathrm{H}-\mathrm{NMR}$ spectra of the Schiff bases (Figure 1) exhibited a singlet peak for the proton of $\mathrm{CH}=\mathrm{N}$ group at (8.26-8.36) $\mathrm{ppm}$. A triplet signal at (3.26-3.63) ppm related to methylene proton of $\mathrm{CH}=\mathrm{N}-\mathrm{CH}_{2}$, while methylene protons displayed as multiplet signal at (1.211.72) $\mathrm{ppm}$. Aromatic protons appeared as doublet signal at the region (6.92-8.13) ppm Table 4. In the ${ }^{13} \mathrm{C}-\mathrm{NMR}$ spectra (Figure 2) of compounds (2-4, 6, 7 and 10), the signal for carbon of $\mathrm{CH}=\mathrm{N}$ groups of compounds showed at (166.1) ppm. A signal appeared at $59 \mathrm{ppm}$ attributed to methylene carbon of $\mathrm{CH}=\mathrm{N}-\mathrm{CH}_{2}$, while the signals of methylene carbons exhibited at (27.2-55.6) ppm. The signals of aromatic carbons exhibited at $(114.2-184.9)$ ppm Table 5 .

Table 3. Spectral data (FT-IR) of N, N'- (alkane-1,7-diyl) and (alkane-1,8-diyl) bis(1-(4-substituted phenyl) methanimine (1-10) :

\begin{tabular}{|c|c|c|c|c|}
\hline \multirow{2}{*}{ Comp.No. } & \multicolumn{4}{|c|}{ FT-IR(KBr) $\mathrm{cm}^{-1}$} \\
\cline { 2 - 5 } & C-H Arom. & $\begin{array}{c}\text { C-H } \\
\text { Alipha. }\end{array}$ & $\begin{array}{c}\mathrm{C}=\mathrm{N} \\
\text { Imine }\end{array}$ & $\begin{array}{c}\mathrm{C}=\mathrm{C} \\
\text { Arom. }\end{array}$ \\
\hline 1 & 3024 & 2926 & 1649 & 1606 \\
\hline 2 & 3020 & 2920 & 1651 & 1606 \\
\hline 3 & 3030 & 2933 & 1643 & 1602 \\
\hline 4 & 3049 & 2933 & 1639 & 1596 \\
\hline 5 & 3089 & 2935 & 1643 & 1560 \\
\hline 6 & 3047 & 2920 & 1645 & 1606 \\
\hline 7 & 3055 & 2922 & 1647 & 1606 \\
\hline 8 & 3055 & 2933 & 1643 & 1608 \\
\hline 9 & 3062 & 2935 & 1643 & 1604 \\
\hline 10 & 3053 & 2924 & 1645 & 1593 \\
\hline
\end{tabular}


Table 4. Spectral data ( $\left.{ }^{1} \mathrm{H}-\mathrm{NMR}\right)$ of N, N'- (alkane-1,7- diyl) and (alkane-1,8-diyl) bis(1-(4-substituted phenyl) methanimine (1- 10):

\begin{tabular}{|c|c|c|c|c|c|c|}
\hline \multirow{2}{*}{$\begin{array}{c}\text { Comp. } \\
\text { No. }\end{array}$} & \multicolumn{5}{|c|}{${ }^{1} \mathrm{H}-\mathrm{NMR} \delta$ ppm } & $\mathrm{CH}_{3}$ \\
\cline { 2 - 7 } \multirow{2}{*}{1} & $1.29-1.68 \mathrm{~m}$, & 3.4 & 8.29 & 7.23 & 3.81 & \\
& $10 \mathrm{H}$ & $\mathrm{t}, 4 \mathrm{H}$ & $\mathrm{s}, 2 \mathrm{H}$ & $\mathrm{d}, 8 \mathrm{H}$ & $\mathrm{s}, 6 \mathrm{H}$ & \\
\hline \multirow{2}{*}{2} & $1.25-1.61 \mathrm{~m}$, & 3.26 & 8.71 & 7.33 & & 2.38 \\
& $10 \mathrm{H}$ & $\mathrm{t}, 4 \mathrm{H}$ & $\mathrm{s}, 2 \mathrm{H}$ & $\mathrm{d}, 8 \mathrm{H}$ & & $\mathrm{s}, 6 \mathrm{H}$ \\
\hline \multirow{2}{*}{3} & $1.21-1.68 \mathrm{~m}$, & 3.43 & 8.32 & 7.98 & & \\
& $10 \mathrm{H}$ & $\mathrm{t}, 4 \mathrm{H}$ & $\mathrm{s}, 2 \mathrm{H}$ & $\mathrm{d}, 8 \mathrm{H}$ & & \\
\hline \multirow{2}{*}{4} & $1.25-1.69 \mathrm{~m}$, & 3.44 & 8.28 & 7.42 & & \\
& $10 \mathrm{H}$ & $\mathrm{t}, 4 \mathrm{H}$ & $\mathrm{s}, 2 \mathrm{H}$ & $\mathrm{d}, 8 \mathrm{H}$ & & \\
\multirow{2}{*}{5} & $1.33-1.72 \mathrm{~m}$, & 3.63 & 8.30 & 7.66 & & \\
& $10 \mathrm{H}$ & $\mathrm{t}, 4 \mathrm{H}$ & $\mathrm{s}, 2 \mathrm{H}$ & $\mathrm{d}, 8 \mathrm{H}$ & & \\
\hline \multirow{2}{*}{6} & $1.27-1.70 \mathrm{~m}$, & 3.37 & 8.26 & 7.24 & 3.81 & \\
& $12 \mathrm{H}$ & $\mathrm{t}, 4 \mathrm{H}$ & $\mathrm{s}, 2 \mathrm{H}$ & $\mathrm{d}, 8 \mathrm{H}$ & $\mathrm{s}, 6 \mathrm{H}$ & \\
\hline \multirow{2}{*}{7} & $1.28-1.70 \mathrm{~m}$, & 3.60 & 7.32 & 7.31 & & \\
\hline \multirow{2}{*}{8} & $12 \mathrm{H}$ & $\mathrm{t}, 4 \mathrm{H}$ & $\mathrm{s}, 2 \mathrm{H}$ & $\mathrm{d}, 8 \mathrm{H}$ & & \\
\hline \multirow{2}{*}{9} & $1.28-1.66 \mathrm{~m}$, & 3.51 & 8.36 & 7.64 & & \\
\hline \multirow{2}{*}{10} & $12 \mathrm{H}$ & $\mathrm{m}, 4 \mathrm{H}$ & $\mathrm{s}, 2 \mathrm{H}$ & $\mathrm{m}, 8 \mathrm{H}$ & & \\
& $1.30-1.69 \mathrm{~m}$, & 3.36 & 8.31 & 7.95 & & \\
\hline & $12 \mathrm{H}$ & $\mathrm{t}, 4 \mathrm{H}$ & $\mathrm{s}, 2 \mathrm{H}$ & $\mathrm{d}, 8 \mathrm{H}$ & & \\
\hline
\end{tabular}

Table 5. Spectral data $\left({ }^{13} \mathrm{C}-\mathrm{NMR}\right)$ of N, N'- (alkane-1,7-diyl) and (alkane-1,8-diyl) bis (1-(4-substituted phenyl) methanimine:

\begin{tabular}{|c|c|c|c|c|c|c|}
\hline \multirow{2}{*}{$\begin{array}{l}\text { Comp. } \\
\text { No. }\end{array}$} & \multicolumn{6}{|c|}{${ }^{13} \mathrm{C}-\mathrm{NMR} \delta \mathrm{ppm}$} \\
\hline & $\mathrm{CH}_{2}$ & $\begin{array}{c}\mathrm{CH}=\mathrm{N}- \\
\mathrm{CH}_{2}\end{array}$ & Ar-H & $\mathrm{CH}=\mathrm{N}$ & $\mathrm{OCH}_{3}$ & $\mathrm{CH}_{3}$ \\
\hline 2 & $\begin{array}{c}27.2-31.0 \\
5 \mathrm{C}\end{array}$ & $\begin{array}{c}59.0 \\
2 \mathrm{C}\end{array}$ & $\begin{array}{c}128.9-142.5 \\
12 \mathrm{C}\end{array}$ & $\begin{array}{c}166.1 \\
2 \mathrm{C}\end{array}$ & - & $\begin{array}{c}21.1 \\
2 \mathrm{C}\end{array}$ \\
\hline 3 & $\begin{array}{c}27.2-31.0 \\
5 \mathrm{C}\end{array}$ & $\begin{array}{c}59.0 \\
2 \mathrm{C}\end{array}$ & $\begin{array}{c}124.7-151.2 \\
12 \mathrm{C}\end{array}$ & $\begin{array}{c}166.1 \\
2 \mathrm{C}\end{array}$ & - & - \\
\hline 4 & $\begin{array}{c}27.2-31.0 \\
5 \mathrm{C}\end{array}$ & $\begin{array}{c}59.0 \\
2 \mathrm{C}\end{array}$ & $\begin{array}{c}129.4-137.1 \\
12 \mathrm{C}\end{array}$ & $\begin{array}{c}166.1 \\
2 \mathrm{C}\end{array}$ & - & - \\
\hline 6 & $\begin{array}{c}27.2-55.6 \\
6 \mathrm{C}\end{array}$ & $\begin{array}{c}59.0 \\
2 \mathrm{C}\end{array}$ & $\begin{array}{c}114.2-184.9 \\
12 \mathrm{C}\end{array}$ & $\begin{array}{c}166.1 \\
2 \mathrm{C}\end{array}$ & $\begin{array}{c}56.0 \\
2 \mathrm{C}\end{array}$ & - \\
\hline 7 & $\begin{array}{c}27.2-31.0 \\
6 \mathrm{C}\end{array}$ & $\begin{array}{c}59.0 \\
2 \mathrm{C}\end{array}$ & $\begin{array}{c}128.9-142.5 \\
12 \mathrm{C}\end{array}$ & $\begin{array}{c}166.1 \\
2 \mathrm{C}\end{array}$ & - & $\begin{array}{c}21.1 \\
2 \mathrm{C}\end{array}$ \\
\hline 10 & $\begin{array}{c}27.2-31.0 \\
6 \mathrm{C}\end{array}$ & $\begin{array}{c}59.0 \\
2 \mathrm{C}\end{array}$ & $\begin{array}{c}129.4-137.1 \\
12 \mathrm{C}\end{array}$ & $\begin{array}{c}166.1 \\
2 \mathrm{C}\end{array}$ & - & - \\
\hline
\end{tabular}

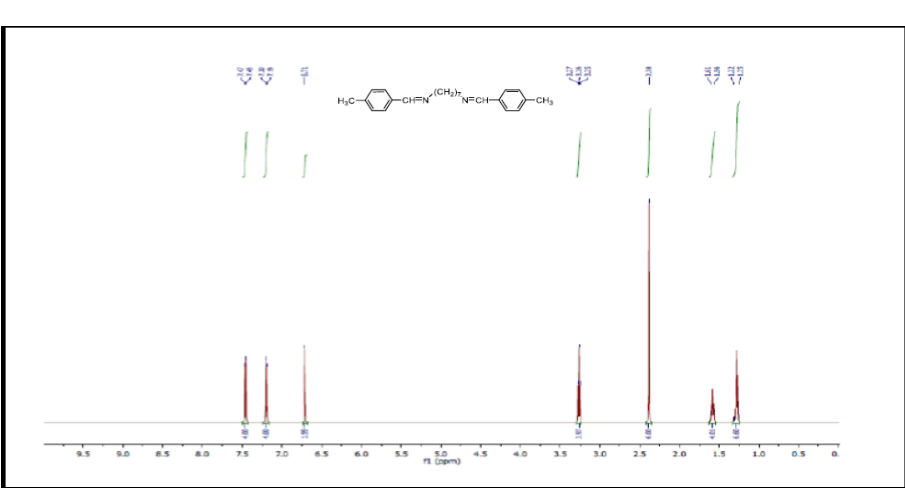

Figure 1. 1H-NMR spectrum of the Schiff base (1E,1'E)-N, N'-(heptane-1,7 -diyl)bis(1-p-tolylmethanmine) (1)

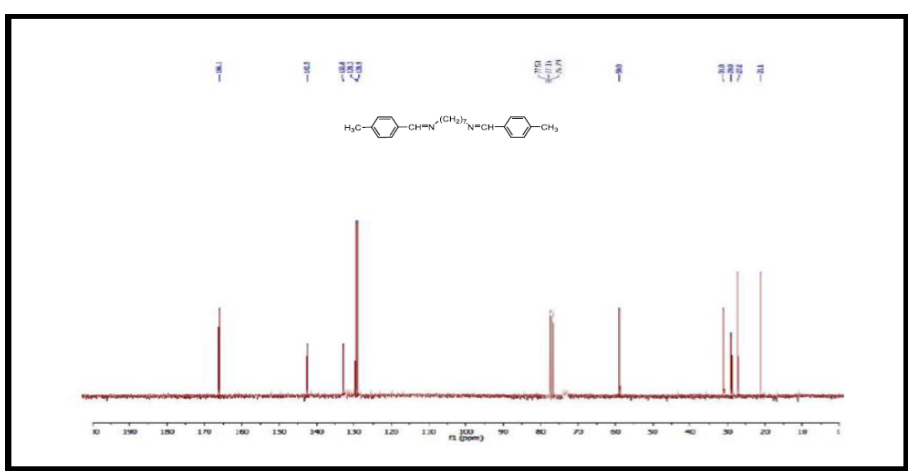

Figure $2 .{ }^{13} \mathrm{C}$-NMR spectrum of the Schiff base $\left(1 E, 1^{\prime} E\right)-N, N^{\prime}$-(heptane-1,7-diyl)bis(1-p-tolylmethanmine) (1) 
The second part focused on the synthesis of five oxazepine derivatives (11-15) by reaction between imine groups of Schiff bases (1-10) and cyclic acid anhydride [ phthalic anhydride] in dry benzene as shown in the Scheme 2. The general feature of the I.R spectra of oxazepine derivatives showed the band at (1705-1782) $\mathrm{cm}^{-1}$ belongs to $(\mathrm{C}=\mathrm{O})$ groups in oxazepane structure and disappearance of $(\mathrm{C}=\mathrm{N})$ group. Also appeared a strong band which belongs to the formation of $(\mathrm{C}-\mathrm{O}-\mathrm{C})$ at $1280-1185 \mathrm{~cm}^{-1}$, this evidence confirmed the formation of the described products Table 6 .

The ${ }^{1} \mathrm{HNMR}$ spectra for oxazepine compounds (11-15) observed a triplet signal of methylene proton attached to nitrogen atom at (3.09-4.04) ppm and showed the proton of the $\mathrm{CH}-\mathrm{N}$ group with protons of aromatic ring as multiplet signals at (6.90-8.23) ppm, which is a good evidence of obtaining the products Table 7 . Furthermore, the appearance of the new extra different carbon peaks in the aromatic at $\delta(109.5-160.2)$ and carbonyl groups at (166.4 and 170.6) ppm regions in the ${ }^{13} \mathrm{C}$ NMR spectra, provided further support to the structures of the oxazepine products Table 8 .

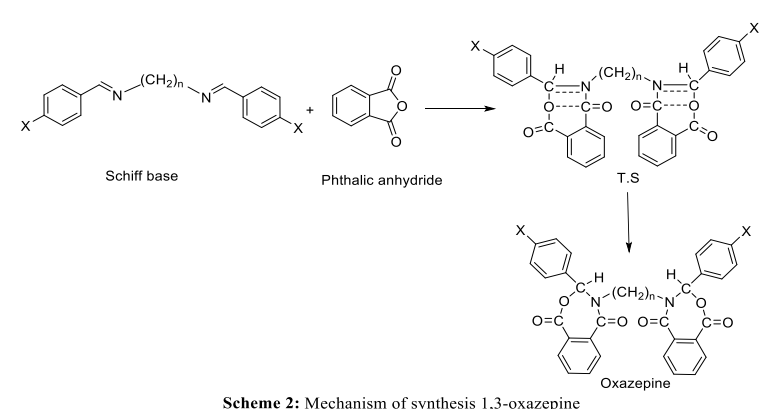

Table 6. Spectral data (FT-IR) of oxazepine compounds (11-15):

\begin{tabular}{|c|c|c|c|}
\hline \multirow{2}{*}{ Comp.No. } & \multicolumn{3}{|c|}{$\mathrm{FT}-\mathrm{IR}(\mathrm{KBr}) \mathrm{cm}^{-1}$} \\
\cline { 2 - 4 } & $\mathrm{C}=\mathrm{O}$ & $\mathrm{C}=\mathrm{C}$ & $\mathrm{C}-\mathrm{O}-\mathrm{C}$ \\
\hline 11 & 1727 & 1615 & 1185 \\
\hline 12 & 1705 & 1607 & 1261 \\
\hline 13 & 1782 & 1615 & 1259 \\
\hline 14 & 1717 & 1585 & 1280 \\
\hline 15 & 1726 & 1616 & 1272 \\
\hline
\end{tabular}

Table 7. Spectral data ( $\left.{ }^{1} \mathrm{H}-\mathrm{NMR}\right)$ of oxazepane compounds (11-15):

\begin{tabular}{|c|c|c|c|c|c|}
\hline \multirow{2}{*}{ Comp. No. } & \multicolumn{5}{|c|}{${ }^{1} \mathrm{H}-\mathrm{NMR} \delta \mathrm{ppm}$} \\
\hline & $\mathrm{CH}_{2}$ & $\mathrm{C}-\mathrm{N}-\mathrm{CH} \mathbf{H}_{2}$ & Ar-H \& C-H & $\mathrm{OCH}_{3}$ & $\mathrm{CH}_{3}$ \\
\hline 11 & $\begin{array}{c}1.28-1.66 \\
\mathrm{~m}, 12 \mathrm{H}\end{array}$ & $\begin{array}{l}3.70 \\
\mathrm{t}, 4 \mathrm{H}\end{array}$ & $\begin{array}{c}7.55-8.23 \\
\mathrm{~m}, 18 \mathrm{H}\end{array}$ & - & - \\
\hline 12 & $\begin{array}{c}1.23-1.63 \\
\mathrm{~m}, 10 \mathrm{H}\end{array}$ & $\begin{array}{l}3.55 \\
\mathrm{t}, 4 \mathrm{H}\end{array}$ & $\begin{array}{c}7.45-8.06 \\
\mathrm{~m}, 18 \mathrm{H}\end{array}$ & - & - \\
\hline 13 & $\begin{array}{c}1.23-1.59 \\
\mathrm{~m}, 10 \mathrm{H}\end{array}$ & $\begin{array}{l}3.69 \\
t, 4 \mathrm{H}\end{array}$ & $\begin{array}{c}7.17-8.06 \\
\mathrm{~m}, 18 \mathrm{H}\end{array}$ & - & $\begin{array}{c}2.34 \\
\mathrm{~s}, 6 \mathrm{H}\end{array}$ \\
\hline 14 & $\begin{array}{c}1.37-1.70 \\
\mathrm{~m}, 10 \mathrm{H}\end{array}$ & $\begin{array}{l}3.78 \\
\mathrm{~m}, 4 \mathrm{H}\end{array}$ & $\begin{array}{c}6.90-8.05 \\
\mathrm{~m}, 18 \mathrm{H}\end{array}$ & $\begin{array}{c}3.42 \\
\mathrm{~s}, 6 \mathrm{H}\end{array}$ & - \\
\hline 15 & $\begin{array}{c}1.21-1.64 \\
\mathrm{~m}, 12 \mathrm{H}\end{array}$ & $\begin{array}{l}3.57 \\
t, 4 \mathrm{H}\end{array}$ & $\begin{array}{c}7.47-8.07 \\
\mathrm{~m}, 18 \mathrm{H}\end{array}$ & - & - \\
\hline
\end{tabular}

Table 8. Spectral data $\left({ }^{13} \mathrm{C}-\mathrm{NMR}\right)$ of oxazepane compounds $(11-15)$ :

\begin{tabular}{|c|c|c|c|c|c|c|c|}
\hline \multirow{2}{*}{ Comp. No. } & \multicolumn{7}{|c|}{${ }^{13} \mathrm{C}-\mathrm{NMR} \delta \mathrm{ppm}$} \\
\hline & $\mathrm{CH}_{2}$ & $\mathrm{C}-\mathrm{N}-\mathrm{CH}_{2}$ & Ar-H \& C-H & $\mathrm{C}=\mathrm{O}$ & $\mathrm{OCH}_{3}$ & $\mathrm{CH}_{3}$ & $\mathrm{CN}$ \\
\hline 11 & $\begin{array}{c}27.5-29.0 \\
6 \mathrm{C}\end{array}$ & $\begin{array}{c}42.1 \\
2 \mathrm{C} \\
\end{array}$ & $\begin{array}{c}123.7-147.2 \\
26 \mathrm{C}\end{array}$ & $\begin{array}{c}166.4,170.6 \\
4 \mathrm{C}\end{array}$ & - & - & - \\
\hline 12 & $\begin{array}{c}27.5-29.0 \\
5 \mathrm{C} \\
\end{array}$ & $\begin{array}{c}42.1 \\
2 \mathrm{C} \\
\end{array}$ & $\begin{array}{c}109.5-142.9 \\
26 \mathrm{C}\end{array}$ & $\begin{array}{c}166.4,170.6 \\
4 \mathrm{C}\end{array}$ & - & - & $\begin{array}{c}119.5 \\
2 \mathrm{C}\end{array}$ \\
\hline 13 & $\begin{array}{c}27.5-29.0 \\
5 \mathrm{C}\end{array}$ & $\begin{array}{c}42.1 \\
2 \mathrm{C}\end{array}$ & $\begin{array}{c}126.1-139.2 \\
26 \mathrm{C}\end{array}$ & $\begin{array}{c}166.4,177.6 \\
4 \mathrm{C}\end{array}$ & - & $\begin{array}{c}21.1 \\
2 \mathrm{C}\end{array}$ & - \\
\hline 14 & $\begin{array}{c}27.5-29.0 \\
5 \mathrm{C} \\
\end{array}$ & $\begin{array}{c}42.1 \\
2 \mathrm{C} \\
\end{array}$ & $\begin{array}{c}112.9-160.2 \\
26 \mathrm{C} \\
\end{array}$ & $\begin{array}{c}166.4,170.6 \\
4 \mathrm{C} \\
\end{array}$ & $\begin{array}{c}56.0 \\
2 \mathrm{C} \\
\end{array}$ & - & - \\
\hline 15 & $\begin{array}{c}27.5-29.0 \\
6 \mathrm{C} \\
\end{array}$ & $\begin{array}{c}42.1 \\
2 \mathrm{C}\end{array}$ & $\begin{array}{c}126.1-147.2 \\
24 \mathrm{C} \\
\end{array}$ & $\begin{array}{c}166.4,170.6 \\
4 \mathrm{C} \\
\end{array}$ & - & - & $\begin{array}{c}123.7 \\
2 \mathrm{C} \\
\end{array}$ \\
\hline
\end{tabular}

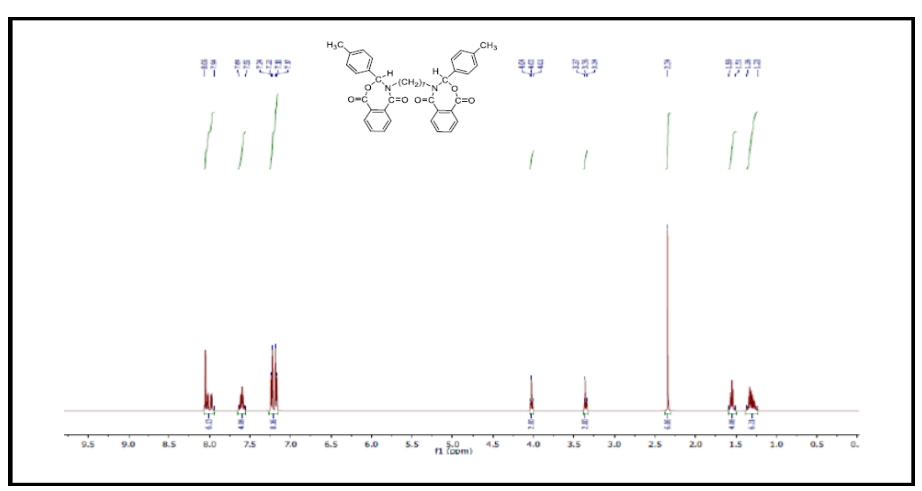

Figure 3. ${ }^{1} \mathrm{H}-\mathrm{NMR}$ spectrum of the oxazepine 4,4'-(heptane-1,7-diyl)bis (3-(p-tolyl)-3,4-dihydrobenzo[e][1,3]oxazepine-1,5-dione) 


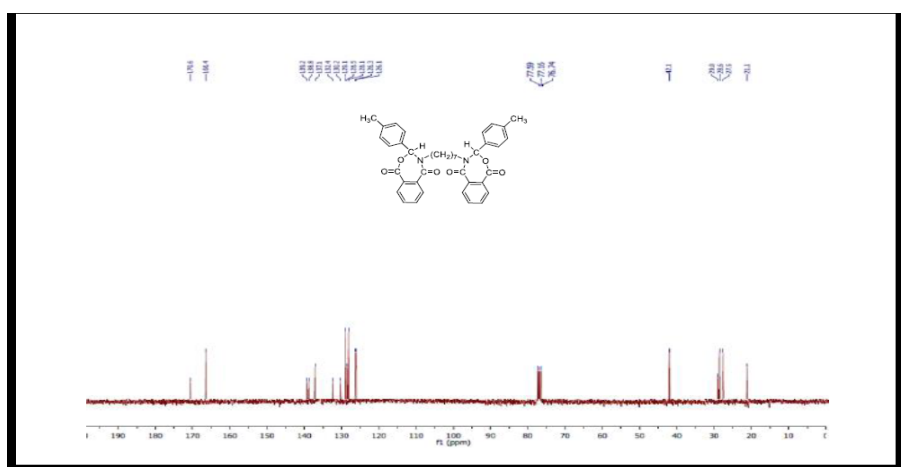

Figure $4 .{ }^{13} \mathrm{C}$-NMR spectrum of the oxazepine 4,4'-(heptane-1,7-diyl)bis (3-(p-tolyl)-3,4-dihydrobenzo[e][1,3]oxazepine-1,5-dione)

The results of such preliminary biological study exhibited that most of new compounds have good antibacterial activity Table 9. The compounds $1,3,5,6,8,9,11,12$ and were sensitive against Escherichia Coli bacteria which represent Gramnegative type. Inhibition of these compounds was similar to that one in

Tetracycline and Nalidixic acid and opposite to the influence of the compounds 2, 7, and 13 which were similar to Lincomycine. The compounds 4,10 and 14 were a moderately sensitive against the type of bacteria. Otherwise, the compounds 2, 4 and 13 have resistant against the Staphylococcus aureus bacteria which represent Gram-positive type and this inhibition were the same as Lincomycine. Furthermore, the compounds 3, 5, 7, 9, 11, 14 and 15 showed sensitive against these bacteria and the result was agreed with that one in Tetracycline and Nalidixic acid. While the compounds $1,6,8,10$ and 14 were moderately sensitive with this kind of bacteria.

Table 9. Inhibition Effect of certain of products on growth of staphylococcus arueus and Escherichia coil.

\begin{tabular}{|c|c|c|c|c|}
\hline \multirow{3}{*}{$\begin{array}{c}\text { Compound } \\
\text { no. }\end{array}$} & \multicolumn{4}{|c|}{ Test organism } \\
\hline & \multicolumn{2}{|c|}{ E.coli } & \multicolumn{2}{|c|}{ Sta. aureus } \\
\hline & $\begin{array}{c}\text { GIZ in } \\
\mathrm{mm}\end{array}$ & Mode & $\begin{array}{c}\text { GIZ in } \\
\mathrm{mm}\end{array}$ & Mode \\
\hline 1 & 23 & $S$ & 15 & MS \\
\hline 2 & 11 & $\mathrm{R}$ & 11 & $\mathrm{R}$ \\
\hline 3 & 22 & $S$ & 20 & S \\
\hline 4 & 15 & MS & 10 & $\mathrm{R}$ \\
\hline 5 & 23 & S & 21 & S \\
\hline 6 & 23 & S & 16 & MS \\
\hline 7 & 10 & $\mathrm{R}$ & 20 & $S$ \\
\hline 8 & 21 & $S$ & 14 & MS \\
\hline 9 & 22 & $S$ & 21 & S \\
\hline 10 & 13 & MS & 16 & MS \\
\hline 11 & 21 & S & 19 & $\mathrm{~S}$ \\
\hline 12 & 22 & $S$ & 20 & $S$ \\
\hline 13 & 10 & $\mathrm{R}$ & 9 & $\mathrm{R}$ \\
\hline 14 & 15 & MS & 14 & MS \\
\hline 15 & 22 & S & 20 & S \\
\hline \multicolumn{5}{|l|}{ Control } \\
\hline Tetracycline & 25 & S & 26 & S \\
\hline Lincomycine & 11 & $\mathrm{R}$ & 24 & S \\
\hline $\begin{array}{l}\text { Nalidixic } \\
\text { acid }\end{array}$ & 22 & $S$ & 10 & $\mathrm{R}$ \\
\hline
\end{tabular}

\section{Conclusion}

A series of new Schiff bases and 1,3 -oxazepine derivatives containing imine group were synthesized successfully using pericycliccyclo addition of Schiff bases with phthalic anhydrides, besides using a small amount of solvents, shorter reaction times and good yield. Some of these compounds shown good antibacterial activity against the bacterial pathogens.

\section{REFERENCES}

A. Abdulqahar, and N. R. Jaber, "Synthesis and Characterization a New 1,3-Oxazepine Compound from New Bis-4-Amino-3Mercapto-1,2,4-Triazole Derivatives", An Indian Journal, vol.12(2), pp. 1-12, 2016.

A. Hameed,"Microwave Synthesis of Some New 1,3-Oxazepine Compounds as Photostabilizing Additives for Pmma Films", Journal of Al-Nahrain University, vol. 15, pp. 47-59, 2012.

A. A. Abedel-Hahez, and B. A. Abdel-Wahab,"5-(4Chlorophenyl)-5,6-dihydro-1,3-oxazepin-7(4H)-one Derivatives as Lipophilic Cyclic Analogues of Baclofen: Design, Synthesis, and Neuropharmacological Evaluation", Bioorganic \& Medicinal Chemistry, vol. 16, pp. 7983-7991, 2008

C. Celik, M. Aslantas E. Sahin, A, Kayraldiz, and M. Tumer, "Structural characterization, genotoxicity and electrochemical properties of the Schiff base ligands and their Ni(II) complexe", J. of Optoelectronics and Advanced Materals", vol. 11(10), pp. 1404, 2009.

E. A. Hallinan, T. J. Hagen, S. Tsymbalov, R. K, Husa, A. C. Lee, A. Stapelfeld, and M. A. Savage," Aminoacetyl Moiety as a Potential Surrogate for Diacylhydrazine Group of SC-51089, a Potent PGE2 Antagonist, and Its Analogs", Journal of Medicinal Chemistry, vol. 39, pp. 609-613, 1996.

H. D. Hanoon, "Synthesis and Characterization of New SevevMembered Heterocyclic Compounds from Reaction of New Schiff Bases with Maleic and Phthalic Anhydrides", National Journal of Chemistry, vol. 41, pp. 77-89, 2011.

H. M. Sadiq, "Synthesis and Characterization of Novel 1,3-Oxazepine Derivatives from Aminopyrazine", World Journal of Pharmacy and Pharmaceutical Sciences, vol. 6(5), pp. 186198, 2017.

H. Agirbas, B. Kemal, and F. Budak, "Synthesis and StructureAntibacterial Activity Relationship Studies of 4-Substituted phenyl-4, 5-dihydrobenzo[f][1,4]- oxazepin-3(2H)-thiones", Medicinal Chemistry Research, vol. 20, pp. 1170-1180, 2011.

J. H. Abdul-wahid, A S. Hameed, and A. K. Mohammed, "Synthesis Characterization of Some New Heterocyclic Compounds Containing1, 3-Oxazepine Ring", Kirkuk University Journal /Scientific Studies, vol. 11(3), pp. 237-247, 2016.

K. F. Hamak, and H. H. Eissa, "Synthesis, Characterization, Biological Evaluation and AntiCorrosion Activity of Some Heterocyclic 
Compounds Oxazepine Derivatives from Schiff Bases", Organic Chem Curr Res, vol. 2(3), pp. 1-7, 2013.

K. Kubota, H. Kurebayashi, H. Miyachi, M. Tobe, M. Onishi, and Y. Isobe, "Synthesis and Structure-Activity Relationship of Tricyclic Carboxylic Acid as Novel Anti-Histamines", Bioorganic \& Medicinal Chemistry, vol. 19, pp. 3005-3021, 2011.

K. Bajajt, V. K. Srivastava, and A. Kumar, "Synthesis of 1, 5Benzothia/Oxazepine as Potent Neuroleptic Agents", Indian Journal of Chemistry. Section B: Organic Chemistry, Including Medical Chemistry, vol. 42, pp. 1149-1155, 2003.

L. M. Prescott, J. P. Harley, and D. A. Klein, Microbiology", $3^{\text {rd }}$ ed. Brown Publisher, London; 1996.

M. J. Al-Jeboori, and A. H. Dawood, "Synthesis and Structural Studies of Novel 2,6-Diformyl-p-Cresol Bis-(thiosemicarbazone) Ligand and Their Binuclear Complexes with $\mathrm{Ni}^{+2}, \mathrm{Pd}^{+2}, \mathrm{Zn}^{+2}$, $\mathrm{Cd}^{+2}$ and $\mathrm{Hg}^{+2}$ Metal Ions," Journal of Kerbala University, vol. 6(1), pp. 268, 2008.

M. T. Khattar, N. M. Aljamali, and K. K. Alasadi, "Synthesis of Heterocyclic Compounds from Imine and Study of Chromatography Applications," Asian J. Research Chem, vol. 7(8), pp. 734-747. 2004.

M. N. Abdullah, J. B. Ziwar, and N. Y. Musheer, "Synthesis of some Heterocyclic Compounds (Oxazepine, Diazepine) using Ultrasound Irradiation," ZANCO Journal of Pure and Applied Sciences, vol. 28(2), pp. 235-239, 2016.

M. H. Serrano-Wu, D. R. St. Laurent, Y. Chen, S. Huang, K. R. Lam, et al, "Sordarin Oxazepine Derivatives as Potent Antifungal Agents," Bioorganic \& Medicinal Chemistry Letters, vol. 12, pp. 2757-2760, 2002.

N. A. Saeed, Ph.D. Thesis, Al-Nahrain University, 2005.

N. M. Aljamali, K. J. Ali, N. S. Salih, and S. H. Ridha, "Synthesis, Characterization and Study of Chromatography Behavior of Novel (Azo-Anil)-Heterocyclic Compounds," Asian J. Research Chem, vol. 7(8), pp. 702-710, 2014.

N. I. Taha, "Synthesis of 1,3-Oxazepine Derivatives Derived from 2(1H-Benzo[d][1,2,3]Triazol-1-yl) Acetohydrazide by Using Microwave Irradiation," International Journal of Organic Chemistry, vol. 7, pp. 219-228, 2017.
N. M. Aljamali, "Preparation and Identification of Macrocycles of Oxazepine Compounds," Journal of Scientific and Innovative Research, vol. 2(1), pp. 53-60, 2013.

N. M. Aljamali, "Synthesis and Identification of Oxazipen ,Diazipene Compounds Via Peri cyclic Reactions," J Chem \& Cheml Sci, vol. 3, pp. 64-69, 2013

P. Verma, S. Gupta, and V. S. Yadav, "Catalyst-Free and Facile Green Synthesis of Some Novel Oxazepine Derivatives," Der Chemica Sinica, vol. 6, pp. 86-89, 2015.

R. Ghosh, SH. Rahaman, C. Lin, TB. Lu, and K. Ghosh, "Coordination behaviour of symmetrical hexadentate N-donor Schiff bases towards zinc (II) pseudohalides," Syntheses, crystal structures and luminescence. Polyhedron, vol. 25, pp. 3104-3112, 2006.

R. M. Al-juburi, "Synthesis and Characterization of Some Heterocyclic Compounds (Oxazepine, Tetrazole) Derived from Schiff Bases," Journal of Al-Nahrain University, vol. 15, pp. 60-67, 2012.

S. J. Wadher, M. P. Puranik, N. A. Karande, and P. G. Yeole, "Synthesis and Biological Evaluation of Schiff base of Dapsone and their derivative as Antimicrobial agents," International Journal of PharmTech Research, vol. 1(1), pp. 22-23, 2009.

S. Mohammed, A. Dawood and M. Mohammed, "Synthesis, Identification and Biological Activity of some Schiff Bases derived from 1,5-diamino naphthalene substrate," Research Journal of Chemistry and Environment, vol. 23(9), pp. 108122, 2019.

Y. H. Jian, S. Wenhua, Z. L. Li, and Z. Ma, "The rapid synthesis of Schiff-base without solvent under microwave irradiation," Chinese Chemical Letters, vol. 13(1), pp. 3-6, 2002.

Z. H. Abood, "Using A pericyclic Reactions for The Synthesis of New 1, 3-Oxazepine Compounds From New Imines," Journal of Kerbala University, vol. 8(1), pp. 354-370, 2010.

Z. H. Abood, R. T. Haiwal, H. T. ghanin, S. M. Radhi, "Synthesis of Some New Schiff Bases, Tetrazole and 1,3-Oxazepine Derivatives Containing Azo Group and 1,3,4- Thiadiazole Moiety," Journal of Babylon University/Pure and Applied Sciences, vol. 21(1), pp. 181-205, 2013. 